\title{
Technology Trends for Business Productivity Increase*
}

\section{Tendencias Tecnológicas que Influyen en el Aumento de la Productividad Empresarial}

\author{
DOI: http://dx.doi.org/10.17981/ingecuc.11.2.2015.09
}

Reflection Article - Reception Date: November 28, 2014 - Acceptance Date: September 22, 2015

Albeiro Patiño Builes

Master in Strategic Management, Católica del Norte Fundación Universitaria. Medellín (Colombia). ajpatinob@ucn.edu.co

To cite this paper:

A. Patiño Builes, "Technology Trends for Business Productivity Increase," INGE CUC, vol. 11, no. 2, pp. 84-96, 2015. DOI: http://dx.doi.org/10.17981/ingecuc.11.2.2015.09

\begin{abstract}
This reflection paper aims to summarize some of the technology trends that companies can use in their business processes to increase productivity and improve the competitiveness of the sector and country. It is based mainly on an official documentation study of both national and international authorized entities. First, some characteristics of the ICT and its influence in companies over the last years are shown; and finally, the conceptualization and benefits that Internet, Telework, e-Learning and Cloud computing represent today to companies in the productive sector are analyzed. It is concluded that ICT, and trends based on them, can make simpler and more agile processes in companies, and also, strengthen their skills to face increasingly demanding markets, whenever globalization and Free Trade Agreements (FTA) call to companies from all sectors to be more effective and efficient.
\end{abstract}

Keywords - Competitiveness, Business, Productivity, Information and Communications Technology -ICT
Resumen-Este artículo de reflexión pretende resumir algunas de las tendencias tecnológicas que pueden usar las empresas en sus procesos de negocio para aumentar su productividad y, por tanto, la competitividad del sector y el país. El autor se ha basado especialmente en el estudio de documentación oficial de entes autorizados, tanto nacionales como internacionales. Inicialmente, se revisan algunas características de las TIC y su influencia en las empresas en los últimos tiempos para finalmente pasar a analizar la conceptualización y los beneficios que Internet, el teletrabajo, la formación virtual y la computación en la nube representan hoy por hoy para las empresas y el sector productivo. Se concluye que las TIC y tendencias derivadas de éstas pueden hacer más simples y ágiles los procesos de las empresas, al igual que más fuertes sus competencias para enfrentar mercados cada día más exigentes, toda vez que la globalidad y la entrada en vigencia de los Tratados de Libre Comercio (TLC) abocan a las compañías de todos los sectores a buscar mayor efectividad y eficiencia.

Palabras clave- Competitividad, Empresas, Productividad, Tecnologías de la Información y las Comunicaciones. 


\section{INTRODUCTION}

In the Competitiveness National Brief 2013-2014 it is established that "Four years have passed and the country (Colombia) has not seen major improvements regarding competitiveness. At least that is what The Global Competitiveness Report 2013-2014 from The World Economy Forum indicates, which, by the way, has become the principal guide in competitiveness matters in the world" [1]. By itself, this statement should constitute a major source of preoccupation; however, there should be even more concern when reading the following statement: "In 2009, the country occupied the $69^{\text {th }}$ place out of 133 countries. Four years later, it is still at the same position, but 148 countries were considered" [1].

This has led to enquire about what is still needed to do in order to be in the right pace, at least, to feel optimistic, in regard to the achievement of what was set up by the Private Council of Competitiveness, this is, "becoming a key agent to transform Colombia (by 2032) into an economy that exports more goods and services with a higher aggregated value, that provides a business environment capable of promoting local and foreign investment, that fosters regional convergence, that improves formal employment opportunities, and that reduces poverty substantially"? [1].

And although there are diverse ways to get ahead, this paper has focused on the new technology trends.

With the advent of Information and Communications Technologies -ICT, especially Internet, and the struggle to position themselves in the market, companies have been forced to change. Traditional methods for information exchange and goods and service buying and selling, as well as the variables that make some companies succeed or, on the contrary, sometimes even disappear, have forced business strategists to think in a different way from how they used to think decades ago. Additionally, as stated by MongeGonzález, Alfaro-Azofeifa, and Alfaro-Chamberlain: "The adoption of ICT by SMEs can be conceived as an important opportunity for Centro American countries due to the implications of this sector's capacity to create more employment and wealth opportunities and, hence, fight poverty in these countries" [2].

At this point, it is not enough just to say ICTs have been gaining ground, it is more than fair to admit that only a few business strategies do not depend on ICTs. Business success today is measured, largely, by the willingness to adopt new ICTs to their existing business models and the company's Time to Market, this is, the time a company takes to implement business solutions and offer them to clients.

ICTs constitute a vital element, basically, in every scenario of the company: work practice; decision making; organizational restructuring generated by the application of the new technology; etc. Furthermore, results from different productive processes in companies are regulated, not to say determined, by the implementation and use of new technologies, especially ICT-related processes.
Companies' economy moves today, to a great extent, thanks to ICTs: invoicing systems; finding, asking, and paying for any product; and liaising of companies and employees, clients, and suppliers are performed using these technologies. Regarding architecture, these professionals use CAD tools to draw their plans. In education, processes are automatized through ICT systems and operate online: students access virtual platforms, interact with their teachers and peers using apps, and even get their grades in this way.

ICTs offer companies great opportunities in the improvement of their processes, as well as in the broadening of their businesses and the opening of new channels and markets. All these features make a good difference for a positive balance outcome. Moreover, as stated by Monge-González, et al.: "if ICTs allow retrenching the few existing resources, it means more investment resources will be available, which in the end, can increase economic growth" [2].

Although the mere investment in ICTs does not represent a substantial improvement in the company's performance -this only happens after a real appropriation of the technologies and their subsequent implementation in the business processes-, it does represent more market prospects, more options for capturing market share, and more alternatives to break boundaries.

Monge-González, et al. mention: "Cost-benefit implications of undertaking ICT-based businesses constitute the cornerstone in the analysis of ICT adoption process by SMEs" [2]. And in this way, a company that makes enormous efforts to invest, as it should, on ICT, on training their employees so as to use these technologies properly, and on adopting them convincingly, at the end, achieves efficiency improvements, suitable cost-benefit relationships, productivity and competitiveness increase and, thus, business volume growth.

The next pages will focus on reviewing some technology trends that can be used by companies to increase their productivity and competitiveness, drawing special attention to these tool's specific functions and the particular benefits to be achieved after implementing them in the business processes. Furthermore, some prospects to serve companies' purposes -SMEs primarily- are presented to increase business possibilities with opportunity, productivity, and competitiveness.

This research is based on searches centered in words like productivity, competitiveness, new technology trends, etc., in areas like Economy, Administration, and Computing, due to its interdisciplinary nature. Journals, books, and reports of multilateral organizations such as the Organization for Economic Cooperation and Development (OECD), the World Bank (WB), and the International Monetary Fund (IMF). The number of times the document consulted appeared, according to the Social Sciences Citation Index, and the publishing date (as recent as possible) were relevant factors to consider any manuscript for this study. 


\section{Characteristics of ICT}

ICTs, as seen in Fig. 1, involve desktop equipment and servers with their respective operational system and software, which is required to operate the computer and install applications. These are interconnected through different means of communication and allow defining electronic networks that provide support to install and integrate all sorts of applications, which are developed using high and low-level programming languages. Among technical service applications are e-mail, chat, and videoconference, and they can be used for several technology trends like telework, virtual education, etc. Other applications have a specific purpose within the company, like client, employee, and supplier relationship management; document management, workflow management; decision making support; etc. All the aforementioned can be seen as a complete but complex solution model backed by interconnection mechanisms, like wired, wireless and satellite networks, interacting with other technologies, like cellular phones and, in many cases, even TV and radio frequency equipment

Now, it is important to note that although SMEs, and companies in general, should try to adopt ICT, the achievements obtained with ICT-based strategies are partially subject to employee, customer, and supplier training in order to be able to connect and interact with these technologies. According to Monge-González, et al.: "A SME's decision to try reaching a high ICT adoption level is the result of many factors. Not only do these include the traditional cost-benefit analysis of any investment decision, but also the complexity of the technology and the training degree of the costumer and supplier network" [2].

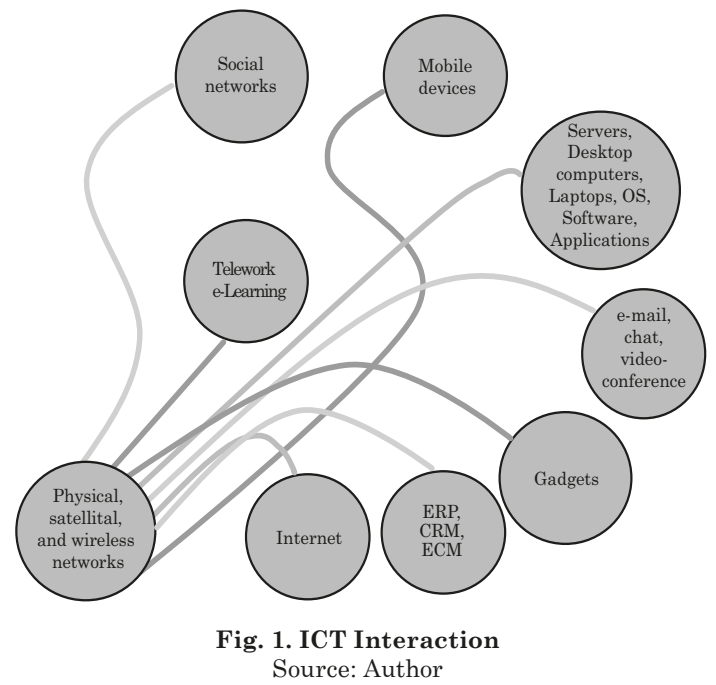

Internet deserves a separate section. The World Wide Web, by allowing the interconnection bet- ween systems around the world, has allowed the realization of the always mentioned Global village, the globalization, and the easy and immediate interaction between people and companies. It is unconceivable to work isolated, as Thomas Alba Edison in a lab, without collaboration and interaction. On the contrary, collaboration, teamwork, and shared achievements are more valued as times passes by; regardless people are sitting next to each other, or if they live far away, internet lets them interact as if they were in the same room.

It is important to highlight that the fundamental aspect concerning ICTs, besides their inestimable value as a tool, does not reside in them per $s e$, but in the possibility for companies to be closer to information and knowledge. Hence, the Information Technology Association of America defines them as "the study, design, development, implementation, support, and management of computerbased information systems, this not only includes computers, the most versatile and used means, but also cellular phones, TV, radio, online newspapers, etc." [3]. From Gimeno's perspective, they are defined as "the usage of $\mathrm{PCs}$ and computer applications to transform, store, manage, protect, disseminate, and locate the necessary data for any human activity" [4].

\section{III.ICT INFLUENCE IN COMPANIES FOR The LAST YEARS}

In accordance to Solow: "Technology is considered the main driving force of growth, and the investment in labor force is second" [5]. Despite the apparent forcefulness of this statement, Solow (just after receiving the Nobel Prize in Economics) also wrote the following words: "You can see the computer age everywhere but in the productivity statistics" [6]. Two contradictory stances. The second, in particular, gave birth to the productivity paradox, and a subsequent large amount of debates. However, these statements help to point out that for a long time both economics and technology researchers have tried to determine to what extent have these sciences supported -still today- the production and growth of companies and, thus, nations. Also, in the same order of ideas, it can be deduced that, from at least thirty years, ICTs have offered their support (although weak) to companies' growth. The productivity paradox, nonetheless, started to fall apart in the 90's when the United States, supported by ICT use, began to show significant signs of growth.

Today, many people advocate for the importance of ICT use in the corporate sector's development. Myro affirms that "Information and Communication Technologies have outstandingly contributed to the high development experienced by world economics in the last years, from 2002 
until mid-2008" [7]. And, the same author continues: "though they have not performed a vital role as they did during the turn of the century in developed countries, ICTs have been permeating the world, fostering the expansion of emerging economies" [7]. Nevertheless, it should be said that the author underestimates the situation, especially in the second part, because with the emergence of social networks, blogs, and other virtual forms of interaction, as of 2005 , people and companies connect between them. By generating changes in the way of thinking and doing, changes have been possible in labor, commercial, educational, and social areas.

Fedesarrollo ${ }^{1}$, in its 2013 report, confirms that "99.9\% of Colombian enterprises are MiSMEs ${ }^{2}$, which corresponds to nearly 1.6 million corporate units" [8]. This can be complemented by stating, as Fedesarrollo [8], that in Colombia, as in the rest of the world, MiSMEs concentrate $81 \%$ of the employees, while their contribution to GDP is only $37 \%$.

Even with this high concentration value, affirms Fedesarrollo in the report, "while in Colombia $52.5 \%$ of low-scale companies are liquidated in the first five years (similar figure to that in the U.S), in countries like Spain or Italy, liquidation probability is 41.4 and $37 \%$, respectively" [8].

In their study, Fedesarrollo expands in the analysis of the reasons for these singularities and finds out that one of them is that "MiSMEs are not very forceful about technology and qualified labor force" [8]. And continues "despite technology investment in companies increased at a compound annual growth rate of $8.6 \%$ in the period 2004 2011 , currently, this represents less than two million COP a year, and besides this, 37\% of MiSMEs do not make any investment of this kind due to tight budgets" [8].

Different researchers in the world have addressed this topic in their works to identify to what extent ICTs have really helped companies, large and SMEs, to enhance their productivity and competitiveness. Results are positive for ICT use in companies. One conclusion drawn from the results, concerning Banegas and Myro cited by Gimeno, establishes that "when analyzing with economics and ICT databases, physically measured for every 100 inhabitants (number of PCs, internet users, landlines, and number of mobile phones), it is confirmed that ICT increases annual growth rate of GDP per capita and productivity at work" [9] cited by [4].

The OECD asserts that "efficiency improvements are likely to happen when processes can be automatic or redesigned in order to free resources

1 Foundation for Higher Education and Development

2 Micro, Small and Medium-sized Enterprises for other projects; when the channels to provide services or operation systems are completely closed; when systems are consolidated; when economies of scale occur between entities" [10].

In [11], Anetcom analyzes different ICT applications and their influence on companies. Results are summarized in Table I. In relation to this analysis and its results, some positive aspects are highlighted, for instance, Gimeno asserts that "all these classifications have in common a wide variety of options offered by ICTs and help companies adapt them to their strategic, organization, and operational schemes in a sensible and efficient manner" [4].

Table I. ICT Applications in Smes

\begin{tabular}{|c|c|}
\hline $\begin{array}{c}\text { Electronic Commerce } \\
\text { Applications }\end{array}$ & e-Business \\
\hline $\begin{array}{c}\text { Marketing and } \\
\text { Communication } \\
\text { Applications }\end{array}$ & $\begin{array}{c}\text { Newsletters, m-mail, } \\
\text { blogs, market } \\
\text { observatories, etc. }\end{array}$ \\
\hline $\begin{array}{c}\text { Client Management } \\
\text { Applications }\end{array}$ & $\begin{array}{c}\text { CRM (Customer } \\
\text { Relashionship Management) }\end{array}$ \\
\hline $\begin{array}{c}\text { Productive Processes and } \\
\text { Logistics Applications }\end{array}$ & $\begin{array}{c}\text { ERP, GPS, Project managers, } \\
\text { document managers, etc. }\end{array}$ \\
\hline $\begin{array}{c}\text { Purchase and Supplier } \\
\text { Applications }\end{array}$ & e-Procurement \\
\hline $\begin{array}{c}\text { Tracking and Monitoring } \\
\text { Applications }\end{array}$ & $\begin{array}{c}\text { Balance Scorecard (BSC), } \\
\text { Business Intelligence (BI) }\end{array}$ \\
\hline $\begin{array}{c}\text { Human Resources } \\
\text { Management } \\
\text { Applications }\end{array}$ & $\begin{array}{c}\text { Intranet, employee portal, } \\
\text { e-Learning, knowledge } \\
\text { management, etc. }\end{array}$ \\
\hline
\end{tabular}

Source: Author

Many are the classifications presented for ICTs aiming at analyzing in detail their contribution to productivity and competitiveness in companies. On the one hand, Sieber \& Valor, summarize them as: webpages and e-Commerce, productivity and teamwork tools, collaboration and portal tools, wireless Wi-Fi/LANS and integrated enterprise resource planning (ERP) [12]; on the other hand, Vilaseca \& Torrent classify them in: mobile telephony, PCs, internet connection, local area network, electronic interchange, webpages and e-mail [13]. The authors of this paper contemplate another valid classification: website in the company's own server, internet-based goods or service purchase, e-Commerce with other companies.

These classifications, and other possible, evidence the great variety of perspectives related to ICTs and their general contribution to companies. The next section will describe some of them: Internet, telework, e-Learning, and cloud computing. Likewise, their contribution in corporate processes will be discussed. 


\section{Technology TREnds}

\section{A. Internet}

Few -very few- people could actually have foreseen the potential and advantages of a solution that started as an experiment: joining two computers through a wire in order to transmit, from one to the other, a simple message "QWERTY". The truth is that those two first computers were like the parents of a huge generation; one composed by millions and millions of desktops, laptops, cellphones, tablets, smartphones, etc., which nowadays are interconnected forming a tangle of cables and devices called Internet, or the Web, or the World Wide Web.

Today, internet is the core of any ICT-based solution. Through internet not only are the different devices interconnected but also facilitate a great amount of services and functions: the first and most popular, e-mail, followed by instant messaging (IM), chatting, remote access, buying and selling of products and services, e-Business, e-Marketing, e-Procurement, e-Learning, etc. All these contribute to a proper client, employee, and supplier relationship, product and resource management, etc.

A new paradigm called ubiquitous computing or ubicomp and characterized, according to Curto Díaz y Conesa i Caralt, by "the proliferation of a technology embedded in devices of multiple nature, the integration of computing in people's everyday life, and the fact that our information or applications are available everywhere" [14] is possible thanks to internet and the new technologies and aims at integrating the cloud.

In this context, companies have started looking at technology, especially ICT, as something more than mere assets; now, they are an essential part of the business that fosters their corporate strategy and their commercial development. And thanks to technology, it is now possible to democratize information and knowledge; besides, it is precisely internet that has permitted the convergence of data, audio, and video services. Ubiquity, then, has become possible. Online governement and banking have seen in internet the opportunity to speed up processes for the final consumer, like reducing costs, both for the costumer and the government and bank. This has resulted in a tangible and considerable increase in the country's productivity. Internet has allowed commerce to increase demand and supply, which, in turn, has increased the market's boundaries in the whole world. Having said that, nowadays, it is important to understand that internet-based data transmission market includes fixed lined broadband and mobile services; this means a significant upsurge in internet access and penetration, even in low-income strata, with the consequent benefits it implies for companies.
According to Curto Díaz y Conesa i Caralt, "the new trends aim at what is known as the Internet Of Things, where objects are able to communicate through sensors connected to networks that use internet protocol" [14]. In this way, the physical world progressively blends with the virtual, to a point where there it is difficult to tell a difference, since reality, today, is not conceived without a virtual component. These new computing systems have made possible, according to Curto Díaz y Conesa i Caralt, "new models for business, process improvement, and cost and risk reduction" [14].

\section{B. Benefits of Internet}

Basically, everything can be found in the web: a document, a text of any sort, a video, everything. Knowledge and globalization have made possible the creation of huge databases and ICTs have enabled their publication and access in a fast, public manner, regardless where the information or the person consulting are. In this way, many displacements, waiting time, and important associated costs have reduced, and therefore, cash flow for companies has improved. A new model of enterprise has born: the virtual, feasible enterprise, one that generates more profit than costs.

Manufacturers of all sorts, including technology, have understood the potential of internet, and in general, of ICTs; for this reason, they have turned to the design, development, and delivery of all types of home and company solutions. For example, assert Curto Díaz y Conesa i Caralt, Google offers all its services on the web (from the search engine to applications that include e-mail, document editing, calendar, etc.); Amazon, a storage service; Salesforce, an on-demand CRM service; Microsoft, a cloud computing platform called Azure; and Abicuo, a Spanish company, created a solution to manage virtual corporate environments in the cloud [14].

Also, a customer appreciates easiness, immediate interaction, knowledge about offered products, and the subsequent value of knowing, before any displacement, any decision making, what to acquire, the price, and the benefits of acquiring it, of course, without moving from home.

And the most important thing is that possibilities are not few; moreover, the horizon of options is very wide, the potential is endless, the benefits are priceless. Aguillo establishes that "from the perspective shown, the ICT sector will continue introducing new and more productive capital into economy, especially into business management, at a lower cost" [15].

The latter does not imply, however, that companies that currently have ICT, hence internet, have productivity and competitiveness granted. Although they are important issuers of strategic solutions, these strategies are the ones in charge of ensuring success. As illustrated in Fig. 2, the creation of a dis- 
tinctive product or service offer in the market is important; this includes bringing value to customers, being difficult to copy, and being demanded. These two premises -ICT and a sustainable product or service- is a winning combination. The lack of any of those pillars, or a deficient implementation of them in the business strategy, will result in greater challenges, sometimes insurmountable, when compared to a proper foundation of them, which is nothing different from the company's directives conviction of betting on this successful blend.

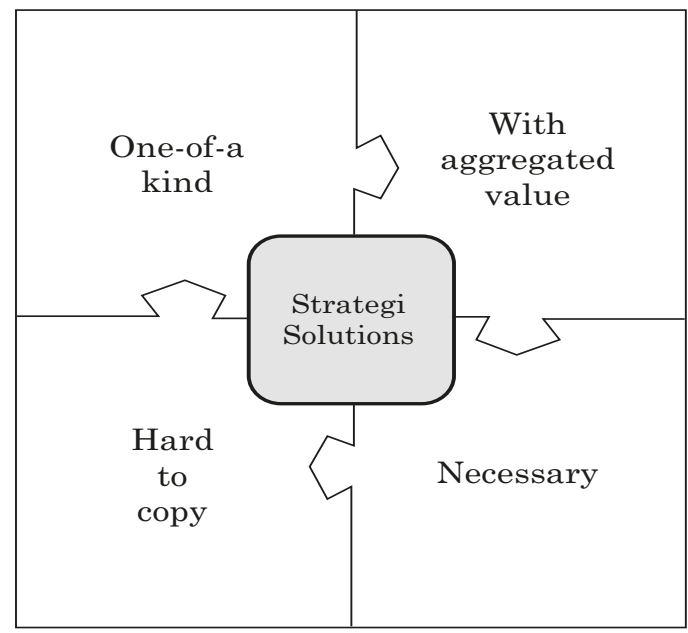

Fig. 2. Characteristics of Strategic Solutions Source: Author

For Gartner, mobile devices will determine internet access. The personal cloud will replace the concept of personal computer. And what the company calls the Internet of Things (IoT), as seen in the present, will have an important effect in the future [16]. The key of internet is the number of technologies that are being incorporated to a great variety of mobile devices, including sensors, image recognition, or payments. Cloud computing, affirms this firm, will lead companies to create cloud services, this are, services offered to customers using this computing model [16].

It is not possible, then, to avoid the world of internet, which, from any stance, always amazes due to the great variety of services offered, and above all, the services that can and will be offered in the future. Other internet-based technology trends, telework and e-Learning, will be discussed in the next sections.

\section{Telework}

In times were employment is difficult due to different reasons, telework appears as an alternative to create work positions at any kind of company without the need of a physical space in the company's head- quarters. Hence, in this model of work the employee is not required to commute in order to work, on the contrary, employees work from home or other location. To complete tasks and achieve objectives, an employee needs ICTs, a PC, internet connection, e-mail, chat, videoconference, VoIP phones, and a VPN so as to ensure communication between his/ her team and the rest of the teams in the company, just as seen in Fig. 3.

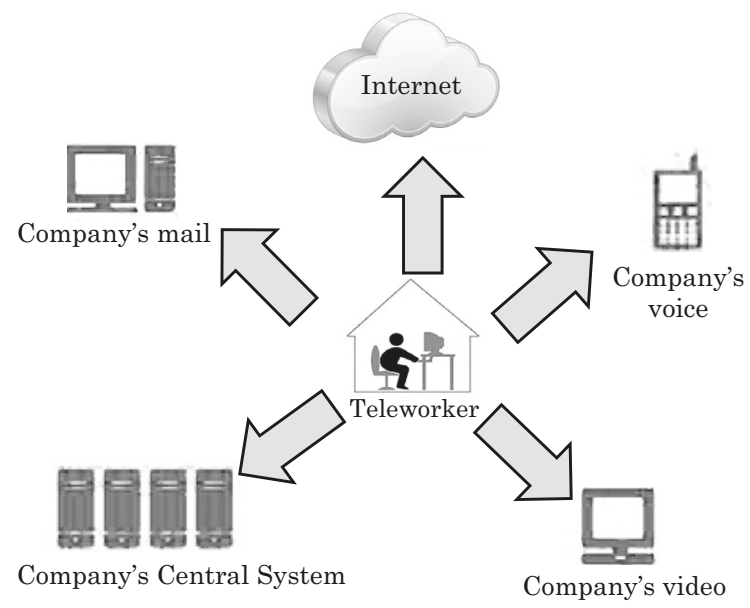

Fig. 3. Teleworker's Connection with the Company's Resources Source: Author

The technical advantages of ICTs have been available for companies for some years now; however, their implementation has delayed due to slow reforms in the regulations of the different countries. The first to authorize this type of work have been, as usual, developed countries like the United States. Colombia has advanced in this topic in the last years. In 2008, Act 1221 was enacted; it defines telework as a "form of labor organization that consists in performing paid activities or providing services to third parties using Information and Communications Technology -ICT- in the communication between the worker and the company, without requiring the physical presence of the worker in a specific workplace" [17].

The objectives for encouraging telework are ambitious: welcome people who are traditionally alienated from work opportunities, like disabled people, women who are head of households, imprisoned people, and people located at distant places from urban zones, etc.

Teleworkers will have a similar treatment to those working at the office: social security, a workday of 6 to 8 hours, etc. However, overtime and night work, as well as transportation allowance do not apply.

Companies entering the official programs of telework will receive different benefits from the government. Incentives aim at motivating entrepreneurs and recruiting as many people as possible into the country's workforce. 
In accordance with Act 1221/2008 [17], three telework modalities are defined: independent telework, or a self-employed worker; supplementary telework, which is performed by a worker with a contract, some days at the company's headquarters, and others, out of the company; and mobile telework, executed by a worker who is permanently absent from the office and uses mobile devices to complete the tasks.

In the first two cases, the following variables are distinguished: full-time teleworker, when the worker never goes to the company; part-time teleworker, when the worker goes to the company at least one day in the week; and complementary teleworker, when the worker goes two or three days a week to the office and works the rest of the time in a different location.

\section{Benefits of Telework}

Many are the benefits observed when implementing telework practices in companies. One of them is the reduction of fixed costs. Although the company has to make a contribution in order to pay for the extra costs related to electricity, phone, internet, and others, and sometimes provide the basic tools the teleworker needs at home, these costs are very low when compared to what is needed to set up a place in the company's headquarters for the worker.

Another important benefit resides in the improvement of the teleworker's quality of life because performing their tasks in this way, allows them to organize better their schedules and manage their time on a daily basis, hence, balancing their personal and work life. In the end, this motivates the teleworker to perform duties efficiently so as to have more time for family activities.

Additionally, teamwork is fostered since, by being outside the company's facilities, the teleworker is forced to seek for different interaction means, e.g. email, chat, videoconference, etc. Through these, the teleworker joins in virtual meetings where he or she interacts with other workers. Objectives, as being shared and corporate, demand from the workers and the company to rely on the "other's" responsibility, or on the fact that "the other" will achieve his/her specific objectives regardless the place this person is in. Attendance is no longer important; the fulfillment of the task for the benefit of a team --and the company's objectives- becomes the most relevant concern.

Also, the social inclusion factor has to be addressed. Telework, as previously noted, makes possible that many people can access work positions, especially, as an alternative for people who, normally, due to different physical, social, and geographical conditions, were unable to access them.

Nevertheless, benefits not only apply for companies and people; the environment, mobility in cities, and the quality of life of families, among other factors, are also favored.
Balanta and Molano have observed and measured other benefits. With the implementation of telework in Colombia, voluntary resignation rates in companies have reduced in a $25 \%$, productivity has increased $23 \%$, and fixed costs related to permanent staff have reduced in an 18\% [18]. These important figures demonstrate that telework is an alternative for substantial improvement in transaction volumes and competitiveness for companies.

Table II shows a list of areas where telework can be implemented.

Table II. Application Areas for Telework

\begin{tabular}{|c|c|}
\hline \multirow{5}{*}{ Management } & Information gathreing \\
\hline & Accounting \\
\hline & Data classification \\
\hline & Business plans \\
\hline & Consultancy \\
\hline \multirow{4}{*}{ Design } & Graphic design \\
\hline & Plans \\
\hline & Translation \\
\hline & Webpage design \\
\hline \multirow{2}{*}{ Technology } & Programming \\
\hline & Technical support \\
\hline \multirow{4}{*}{ Commercial } & Customer service \\
\hline & Purchase/Sell orders \\
\hline & Sales quotes \\
\hline & Marketing \\
\hline \multirow{5}{*}{ Education } & Course design \\
\hline & Handbook/Manual construction \\
\hline & Tutoring \\
\hline & Research \\
\hline & Assessment of papers \\
\hline
\end{tabular}

Source: Author

\section{E. E- Learning}

Virtual learning is the education modality that uses ICTs to impart knowledge to students, who, in turn, are not in a physical classroom (breaking with spatial, time, age, and occupation restrictions), but connected in a virtual classroom through a PC. In this sense, it combines processes (computer and communication-based learning) and applications (collaborative portals and virtual classrooms) to deliver contents to students, using resources like 
internet, e-mail, forums, chat, wikis, texts, audio, video, images, among other tools.

In this way, e-Learning breaks with the traditional model of education and fosters a paradigm shift in which students need not be in physical classrooms anymore to learn. On the other hand, it promotes, through technology tools, communication and collaboration networks.

Nonetheless, it is important to inquire, as $\mathrm{Pa}$ bón Figueras, if ICT permits group learning [19]. To answer this, the author retorts to other authors and presents, to uphold her arguments, a list of eLeraning benefits:

"Allows students to begin from their own starting point and their own pace; reinforces learningoriented processes and not teaching; tutors become facilitators and not just knowledge providers; collaborative learning and interaction are developed by means of a virtual classroom; fosters a broader student participation; reduces social and language inequality factors; learning and interaction records are preserved so as to help in review and reflection processes" [19].

Pedagogical methods, then, are forced to evolve. The teacher is no longer in front of a group of students transmitting, in one direction only, some established knowledge in order to assess their memory skills later. Now, participation is fundamental, the discussion of different points of view, both from the teacher and the students, is a core element; collaborative construction of knowledge and teamwork impose; and analysis ability is highly valued, as well as the validation of the individual perspectives of the participants in the teachinglearning process.

Gutiérrez Rodas establishes that e-Learning involves the implementation of a technology platform in which processes, contents, and services are loaded and configured in order to ensure the teachinglearning process. So far, this is not different from classroom teaching, the difference resides in the means used to establish communication between the actors in the educational process [20].

E-learning has been used by state entities to cover needs of the society; by important universities like the University of Phoenix Online or Sylvan Learning Systems; also, some companies have found in this alternative, a solution to train and educate their employees.

A Spanish journal, the Learning Review, specialized in e-Learning conducted a survey among some of its readers -independent consultants, education institutions, multinational companies, universities, SMEs, and public institutions- with the idea to know what type of virtual training tool were using in their organization. Results showed the level of penetration that e-Learning platforms had achieved to the date (2003) in the organizations. For instance, at that time, an important percentage of multinational companies (25\%) and SMEs (27\%) were inclined towards having their own platform. Open source platforms already had a good reception (an average of $22 \%$ ). Synchronous platforms, at first sight, were the most popular (an average of 20\%). However, it is evident how SMEs remained laggard in terms of platform implementation: $29 \%$ did not have any installed [21].

\section{F. Benefits of e-Learning}

More and more companies' conviction about their responsibility for training their employees is evidenced. Moreover, Katz asserts that "the certainty of ICT's positive impact on economy has begun to prove itself as computing workers' productivity increases in the performance of their tasks" [22]. And, which is the best way to combine this conviction and the need in regard to employees?

The alternatives, until a few years ago, were served in two ways: face-to-face learning and blended learning. Nonetheless, a new flavor has entered the menu: e-Learning, and it is increasingly gaining ground in companies, especially, in Human Resources departments, which traditionally have been responsible for employees' training plans.

There are no limits regarding programs or topics. As illustrated in Fig. 4, technically-oriented or Vocational Education and Training courses for professionals, consulting or management consulting, technically-oriented programs for non-professionals or production project consulting, certification courses, seminars, conferences, lectures, forums, and more, can be instituted. Everything becomes real in the virtual world.

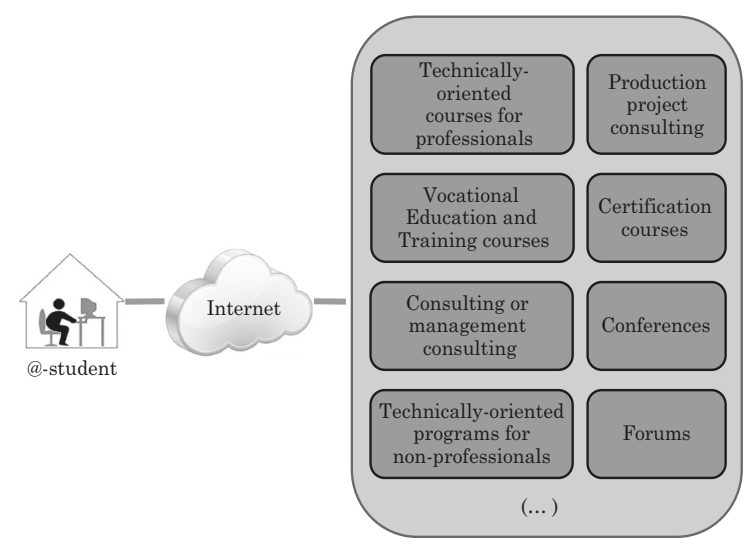

Fig. 4. E-Learning Model Source: Author

Many are the advantages offered by e-Learning. On one hand, it is totally eco-friendly; all the resources needed to teach and study, review and take evaluations, are in PCs and the web. It is not necessary to use large amounts of paper, documents 
are electronic formats and they can be exchanged likewise, even books are digitized or can be consulted from hundreds of virtual libraries available online; hence, printing becomes preventable. This represents an enormous advantage for the planet since it is well known that today the environment needs all the help humans can provide so as to prevent the negative consequences from the greenhouse effect; keeping trees intact is one way to help.

Another important advantage of e-Learning is that it allows students to choose their schedules and place, during the day or at night, hours or minutes, at home or work. Pabón Figueras affirms that "it is obvious that face-to-face communication is reduced between the agents in the process, limiting, mainly, the potential of nonverbal communication. But, in return, learning individualization takes place when schedules are flexible, which is a transcendent matter for adults with multiple responsibilities and occupations" [19].

If this concept is transferred to the labor environment, workers can define the schedules in which they can study without affecting working hours. Many companies, as it should, encourage their employees to develop training activities during working hours, however, this sometimes becomes difficult since labor activities can multiply, and they cannot wait. Thus, the opportunity to study at home and at different hours is a huge advantage, for both, employees and the organization.

Now, studying without time pressure permits students greater meditation and analysis; a crucial element to assimilate contents and a systematic appropriation of knowledge. Without doubt, this will improve employees' productivity, and hence, companies' competitiveness; more educated workers with theoretical foundations and more resources online, means they can increase their production, reduce their mistakes, work with more confidence, become more innovative and efficient, and find more and better solutions to problems.

For companies, besides all that has been said, training their employees using virtual resources means that they can promote the use of the technology they have invested in. Likewise, transportation, lodging, and sometimes, travel allowances for employees training at different locations can be reduced.

Consequently, e-Learning allows companies (though governments can also be included if public education is involved, as well as private education institutions) to reduce costs in features like facilities and teachers; saving time; and reach more people and regions if they are all over the country.

To sum, a wide variety of inconveniences like age, social class, economic situation, schedule requirements, physical disabilities, and many more, can be compensated through virtual education. Particularly, in the case of enterprises, training employees becomes an investment for them, and start profiting from the priceless strengths of this practice still misused; for instance, fostering one's knowledge of the business by replicating it in new employees entering the company and saving money by training not just one person but several at the same time. To end with, this is a system that yields great benefits because it adds value to both the company and its employees.

On the other hand, and as Pabón Figueras asserts, "ICTs result especially useful when assessing students through questionnaires or multiple-choice questions. Tutors receive feedback easily, and they can plan remedial activities when needed" [19].

Additionally, companies have the opportunity to create personalized training courses to cover specific topics by adjusting the knowledge to be taught in accordance with punctual labor needs and assessing in real-world practices the new knowledge students acquired, who, in turn, can objectively and consistently use this knowledge afterwards in favor of the company.

\section{G. Cloud computing}

IT industrial networks were conceived, in general terms, as a series of desktop computers connected to large central processing systems. Connectivity then was not as developed as today, and controllers needed to be installed between desktops and central systems. These controllers sometimes were serial and had a limited capacity for 4-8 computers; these limitations were as evident as substantial. Disconnection of any computer interrupted the whole network; moreover, to connect a significant quantity of computers, many controllers were necessary.

The evolution of this technology led to smart computing. Although central systems still existed, at the time, intermediate servers were conceived (where great part of data processing was downloaded). These servers acted between the central systems and the working stations (which also had enough processing, memory, and disc capacity to process data volumes). Controllers changed for switches and routers; network topologies changed from serial to star and ring, and sometimes, to hybrid topologies. Most of the problems of that first generation abovementioned disappeared. And despite other kind of inconveniences arose, these networks are easier to segment, monitor, and manage.

Nonetheless, times change and so does technology, and it ends up proposing solution schemes that sometimes seem as systems from the past. This is what happens with cloud computing. "A new paradigm that offers services through internet", as Curto Díaz \& Conesa i Caralt establish [14]. Again, big central systems embrace great value. Hundreds 
and thousands of working stations are connected to them. In this modality, most of the intermediate servers disappear to give way to telecommunications, understood as the switches, routers, and channels of communication, mostly internet, which becomes the pillar. Work stations do not require powerful processors or large amounts of memory or storage anymore; they are called thin client precisely because they need the minimum resources to connect to the web and the central system. So, the main application is the browser or thin client.

The basic idea about cloud computing is that everything the user creates, processes, or consults, is in the cloud, this is, internet. Curto Díaz \& Conesa i Caralt assert that "in the last years, these types of service have become popular among the main manufacturers; they are part of the available options in their service portfolios, and even in some cases, they become the predominant or total component" [14].

The National Institute of Standards and Technology (NIST) defines cloud computing as "a model for enabling ubiquitous, convenient, on-demand network access to a shared pool of configurable computing resources (e.g., networks, servers, storage, applications, and services) that can be rapidly provisioned and released with minimal management effort or service provider interaction" [23].

Cloud computing could be seen as another term in the already long list of technology jargon next to terms that support its implementation like hypervisors, virtualization, SOA, web services, provisioning, quality of service, service level agreements, resource monitor, safety, confidentiality, privacy, integrity, etc. Nevertheless, each of these names drags a concept, hence, a tool or function that supports others.

Cloud computing is supported on many of the aforementioned tools. All of them imply implementation and configuration, and afterwards, they need to be supported, updated, and maintained in order to guarantee an adequate service to customers. In general terms, as Curto Díaz \& Conesa i Caralt establish, "cloud computing is considered to be a natural evolution of ASP (Application Services Provider) given that currently there is the appropriate level of technology" [14].

Mostly, understanding cloud computing implies, in turn, the understanding of three domains: first, the characteristics; second, the service models; and third, deployment models.

Regarding the characteristics domain, internet access should be mentioned, which can be from any place and without the need of client installations in the stations, only through the use of a browser or thin client. Also, flexibility and speed are relevant matters; this means the user can increase or reduce the workload without the need to notify the provider previously. Supervised service implies that the provider is fully responsible for the service hired by the customer. Finally, service sharing presupposes that the provider offers basic services to all the clients, who, in turn, have to accept them just as they are in order to prevent the distortion of service level agreements.

Regarding the service models domain, the following are comprised: SaaS (Software as a Service); PaaS (Platform as a Service); and IaaS (Infrastructure as a Service) [14].

Finally, concerning the deployment models, three need to be mentioned: public cloud when the infrastructure is property of an entity; private cloud when it belongs to an entity that uses it for its own behalf; and hybrid cloud when there are two or more clouds involved of public and private nature, which although separated, they are interconnected to provide a service to a particular entity.

Fig. 5 illustrates a cloud computing model that distinguishes the different layers composing the cloud, as well as the domains regulating it.

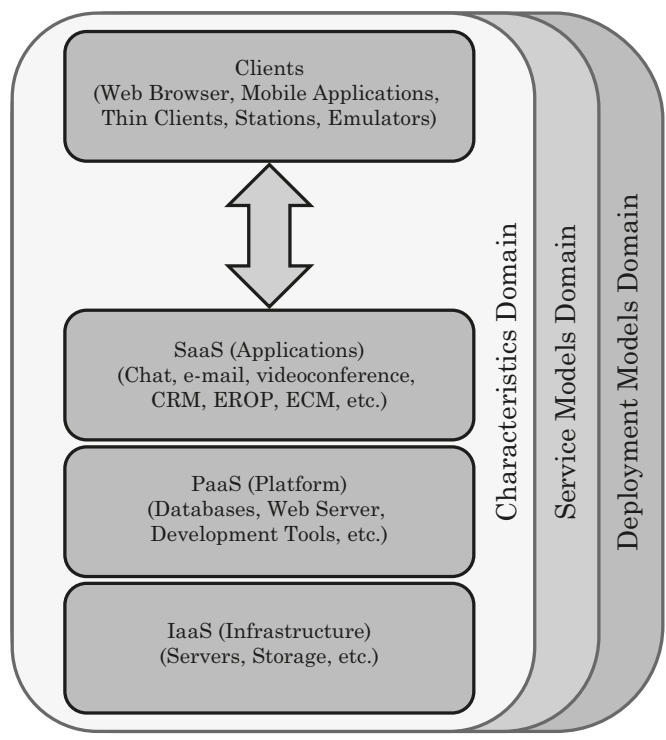

Fig. 5. Cloud Computing Model

Source: Author

Deloitte, in one report, makes reference to the areas with more growth in the last years regarding the use of cloud computing services; these are: Infrastructure as service; Content, communications, and collaboration; Customer Relationship Management-CRM; Supply Chain Manager; Human Resource Management [24].

\section{H. Benefits of Cloud Computing}

As already established, one of the main benefits of cloud computing is for the environment and climate change. By centralizing and optimizing resou- 
rces, cloud computing guarantees saving electricity. The central system and thin clients reduce energy consumption in the distributed working stations due to the minimum processing, memory, and disc required when compared to traditional desktop computers.

Now, through virtualization, all the resources in a system can be distributed in order to be used by any process or application that requires them. In the traditional processing way, maximum resource use is between $15 \%$ to $20 \%$; whereas with cloud computing it can reach a $100 \%$.

When there is a central system and thin clients as distributed stations, storage stops being redundant. As users have more storage, part of it in their working stations and another part in the central system, they tend to use both storage types at random. Having a central system not only ensures storage space optimization but also limits management to the centralized space and minimizes it in the distributed stations.

Customization, configuration, updates, as well as audits and log management, and more, are performed in the central system, hence, saving a lot of work and time because these actions are executed just once instead of doing them in many systems. This also assures that the organization's policies, standards, and other guidelines are preserved.

With cloud computing, users will be able to communicate (e.g. e-mail, chat, VoIP, videoconference, etc.) through a unified system, avoiding the presence of different servers, which in normal conditions would demand a lot of work so as to integrate them.

Theoretically, cloud computing scalability is limited, this means the customer uses the services as much as desired, including resources and the number of user's licenses, and the provider then bills for the real consumption.

Cloud computing is easier to support, update, and maintain than the current model. The customer, as enterprise, disclaims any of these responsibilities; this permits that employees use their time in other activities on behalf of the business, leading to productivity increase and competitiveness enhancement.

Associated costs for technology are considerably reduced as investment for computer purchase, support, update, and maintenance decrease, as well as the development and implementation of new products and services, among other features.

As cloud computing is a series of services (email, storage, etc.) thought to be for massive audiences at first, they are free. When there is a charge (normally for enterprises), this is lower than the cost of buying the same technology from a different source. Besides this, these services can be easily accessed through PCs, laptops, smartphones or tablets.
In general terms, this is a highly valuable alternative available for a low cost that guarantees technology enablers for functional and product developments in the company, regardless of the amount of resources.

\section{Conclusions}

This paper has addressed internet and other ICT alternatives that enable productivity and competitiveness increase in companies (telework, e-Learning, and cloud computing), however, many are the tools and trends still pending for discussion; for instance, IT management tools. These tools (e.g. software distribution, distributed monitoring, remote control, centralized event monitoring, inventory management, etc.) allow IT areas to simplify processes, reduce costs, foster agile technology operations, and more. There are also management support tools like Enterprise Resource Planning -ERP and Customer Relationship Management CRM that support corporate and commercial tasks, assisting the company in aspects such as the relationship with customers, employees, suppliers, and business partners. Some of their contributions are the reduction of management costs and more effective relationships and corporate processes.

It is evident that internet is not new per se, nonetheless, the (still little) use that companies make of the web show that, hitherto, there is a lot of available potential for this resource. Moreover, in some companies believe that employees' access to the web reduces their performance, and sometimes, directives make the decision of closing, or at least limiting, this access for most of their personnel. This fear, precisely, has led many entrepreneurs to stop developing and implementing these tools and services, and on the contrary, turn their backs to an unlimited world of potential and new business opportunities.

Still today, many people embrace Solow's famous productivity paradox, however, despite all this, it is undeniable that ICTs foster business processes of companies, and as they are implemented in these processes, companies achieve a better position in the world's productivity and competitiveness ranking.

The truth is that, apart from the results companies achieve in their productivity and competitiveness levels, every year more and more devices and technology trends enlarge ICT's list; hence, the more time passes, the more devices and technology available.

With the birth of ICT, enterprises found a series of tools that fostered their productive processes and helped them become more competitive. In the last century, developed countries achieved significant growth signals when implemented ICTs in their business processes. In this century, although not 
achieving the same levels of progress than developed countries, emergent countries have managed to improve their productivity and competitiveness levels.

It becomes obvious that the mere implementation of ICTs in productive processes does not produce a productivity improvement. It is necessary, then, to understand that companies should invest in qualified workforce and their training. As stated before, there are two main aspects fostering productivity in enterprises: first, ICT investment, and second, workforce investment.

It has been mentioned that the search of productivity and competitiveness increase is limitless with the aforementioned tools. Since 2005, a new family of ICT-based innovations has arisen: social networks, blogs and nanoblogs, 2.0 and 3.0 web, and all their new functions and interactivity renew the ICT resource portfolio so as to be incorporated into productive processes and enhance corporate, commercial, and educational work.

The paper also discussed how some organizations have conducted studies to determine to what extent the different productive industries have used ICT to support their activities in their companies (Spain); their results indicate that SMEs still need a lot of work to do. This is disquieting taking into account that SMEs constitute (depending on the country) more than $80 \%$ of production enterprises.

In Colombia, the situation is not different. SMEs entrepreneurs understand the importance of ICT implementation in their productive processes to increase productivity and competitiveness in their businesses; however, many still perceive this type of investment as a luxury. Additionally, SMEs that do invest in ICTs not always know why they do it. This confirms the necessity to introduce programs (e.g. consulting, monitoring, design, and implementation) that aid these companies in using these tools properly. This is a huge responsibility (among others regarding ICT) that the government has with enterprises as a promoter of economic policies in the country.

Companies with this vision are able to interact more clearly with the world. They offer their products through portals and corporate websites, sell their products or services through these sites, and pay their suppliers through the same means; this implies that these companies perform a bi-directional move of money: when they sell and when they buy, leaving behind the traditional ways of cash or checks. Besides, internet assists these companies in reaching further into international markets without incurring in travelling expenses; an advantage that cannot be avoided by companies today.

E-Learning aids companies train their employees by bringing knowledge to their desks. And there is nothing more valuable than a well-prepared staff that has the basic and necessary knowledge to fulfill their roles, not just interested in enhancing their skills but ready at any moment to access training resources.

Telework encourages companies to be in different places (e.g. in regional, national, and international environments) at a much lower cost and with the flexibility of increasing their payroll without the necessity to grow its infrastructure (buildings and workplace adaptations).

Cloud computing grants companies great flexibility: increase technology infrastructure without incurring in computer and software purchase, as well as augment and reduce this resource when required without effort or personnel (if purchasing and/or selling this technology). Nowadays, entrepreneurs can hire at very low costs service companies from different parts of the world, like the United States or India, that provide permanent support, guaranteed flexibility and availability the seven days of the week during the whole year.

All the abovementioned trends are just starting to be embraced by the Colombian audience. Large companies are first to face these changes, hence, the first to be favored by them. SMEs, on the other hand, are the most laggard in this path, although due to globalization, economies of scale and the speed in which technology moves, they are the ones which can obtain more benefits from these trends and novel management guidelines.

What has just been said, allows adding that this paper is not only about technology, it is also, and maybe largely, about administration. Technology cannot be seen as a mere machine that occupies a space and that sometimes simplifies processes in companies; it should be seen as a manner of simplifying operations, automatizing processes, reducing the number of people that are required to perform tasks, cut time of processes, and so on. This undeniably translates into cost reduction. And here is when it should be highlighted that not only technicians need to analyze technology trends and try to sell them to directives; also, and maybe more forcefully, directives need to promote technology appropriation and ask, demand, that they are implemented, strengthen, and that provide benefit.

Efficiency consists of offering more with fewer resources; more products and/or services with fewer raw materials; more products and/or services with less human capital (which can rather be producing more, improving processes, increasing profit for the business); more products and/or services for a lower cost. Here is when new technology trends are embraced to increase productivity.

When Solow set up his productivity paradox, he really intended to express that technology should be implemented, but as technology per se. His idea was to show how this technology helped in improving the economic indicators of the company. And this how is precisely what this paper has tried to highlight. 


\section{REFERENCES}

[1] Consejo Privado de Competitividad, "Informe nacional de competitividad 2013 - 2014,” 2014. [Online]. Available: http://www.compite.com.co/site/wp-content/ uploads/2013/11/CPC_INC2013-2014-Informe.pdf.

[2] R. M. Gonzalez, C. Alfaro-Azofeifa, and J. Alfaro-Cham berlain, TICs en las PYMES de Centroamérica: Impacto de la adopción de las tecnologías de la información y la comunicación en el desempeño de las empresas. IDRC, pp. 20, 2005.

[3] Asociación Americana de las Tecnologías de la Información, "Tecnología de información y Comunicación," 2012. [Online]. Available: http://www.parlamentoandino.org/ csa/documentos-de-trabajo/informes-ejecutivos/27-tecnologias-de-la-informacion-y-la-comunicacion-tics.html

[4] V. Alfonso Gimeno, La influencia de las nuevas tecnologías de la información y las comunicaciones y su repercusión en las estrategias empresariales: La banca online y su aplicación en las cooperativas de crédito, Universitat de València, Valencia, 2010.

[5] R. M. Solow, "La teoria del crecimiento y sus alcances," in American Economic Review, 1987.

[6] R. M. Solow, "We'd better watch out," The New York Times, 1987. [Online]. Available: http://www.standupeconomist.com/pdf/misc/solow-computer-productivity.pdf

[7] R. Myro Sánchez, "Las TIC y el crecimiento de la economía española," Economistas, vol. 27, no. 121. Colegio de Economistas de Madrid, pp. 8-16, 2009.

[8] Fedesarrollo, "El papel de las TIC en el desarrollo de la pequeña empresa: reflexiones de política a la luz del caso colombiano," 2013. [Online]. Available: http://www.fedesarrollo.org.co/wp-content/uploads/2013/12/TIC_diciembre_2013.pdf.

[9] R. Myro, Impacto de las tecnologías de la Información en la Economía Española. Madrid: Fundación BBVA, 2007.

[10] OECD, Colombia: La implementación del buen gobierno. OECD, 2014

[11] Anetcom, Las TIC en la estrategia empresarial. Valencia: Anetcom, 2007.

[12] S. Sieber and J. Valor, Las TIC como agentes de cambio en las empresas españolas y su evolución en el período 2005 a 2007 y tendencias de futuro. Barcelona: Pearson, 2008.
[13] J. Vilaseca i Requena, J. Torrent i Sellens, C. F. Cabañero Pisa, D. Castillo Merino, R. Colomé i Perales, Á. Díaz Chao, P. Ficapal-Cusí, A. I. Jiménez Zarco, J. Lladós Masllorens, M. J. Martínez Argüelles, A. Meseguer Artola, D. Plana Erta, and I. Rodríguez Ardura, "Les TIC i les transformacions de l'empresa catalana. Informe de recerca II," Universitat Oberta de Catalunya. Internet Interdisciplinary Institute (IN3), Calatayud, 2003.

[14] J. C. Díaz, Introducción al Business Intelligence. Editorial UOC, 2012

[15] C. Agulló, "Cambios significativos en el mundo empresarial," Economía industrial, no. 330. Ministerio de In dustria, Energía y Turismo, pp. 11-18, 1999.

[16] R. Arroyo, "Gartner: Las tecnologías que causarán furor en 2013," 2012. [Online]. Available: http:// www.channelbiz.es/2012/10/25/gartner-tecnologias2013/\#fEu6hC334o3A0a40.99

[17] Ley 1221 de 2008, Artículo 2. (s.f.). Diario Oficial No. 47.052 de 16 de julio de 2008 .

[18] Ministerio de las Tecnologías de la Información y las Comunicaciones, Libro Blanco. ABC del teletrabajo en Colombia, vol. 3. Colombia: Corporación Colombia Digital, 2012.

[19] M. Pabón Figueras, Impartición de acciones formativas para el empleo: Educación a lo largo de toda la vida. Formación permanente, 1st ed. Vigo: Ideaspropias Editorial S.L., 2014

[20] J. A. Gutiérrez Rodas, Definición de un modelo pedagógico para la educación virtual en el Ces. Medellín, 2004.

[21] "Learning Review," 2008. [Online]. Available: http:// www.learningreview.com/downloads?func=startdown \&id=308.

[22] R. L. Katz, El Papel de las TIC en el Desarrollo. España: Ariel, 2009.

[23] P. Mell and T. Grance, "Recommendations of the National Institute of Standards and Technology," 800-145, 2011. [Online]. Available: http://csrc.nist.gov/publications/nistpubs/800-145/SP800-145.pdf.

[24] Deloitte, "Cloud Computing: Diez cosas que un Director debería saber," 2011. [Online]. Available: http://moodle2.unid.edu.mx/dts_cursos_mdl/pos/TI/IE/AM/09/ Cloud_computing.pdf. 